\title{
High coral cover at lower mesophotic depths: a dense Agaricia community at the leeward side of Curaçao, Dutch Caribbean
}

\author{
Bert W. Hoeksema ${ }^{1,2} \cdot$ Pim Bongaerts ${ }^{3}$ - Carole C. Baldwin ${ }^{4}$
}

Received: 29 September 2015 /Revised: 9 December 2015 / Accepted: 14 December 2015 /Published online: 29 January 2016

(C) The Author(s) 2016. This article is published with open access at Springerlink.com

\begin{abstract}
Coral cover at lower mesophotic depths (particularly $>75 \mathrm{~m}$ ) by zooxanthellate scleractinians is usually very scarce, largely due to the extremely low irradiance levels at these depths. An exception are the Leptoseris communities observed near the Hawaiian islands (Central Pacific) that form dense fields, supporting a broad range of associated organisms. Here, we describe a similar high-cover coral community at lower mesophotic depths, but in the Caribbean. The community was observed on the leeward side of Curaçao (Southern Caribbean) using a manned submersible (Curasub), and was predominantly composed of plating Agaricia corals and an assemblage of reef fishes. Some of the fish species were known from similar depths at other localities, whereas others obtained new depth records. Future surveys are required to establish the extent of similar highcoral communities around Curaçao, and more broadly in the western Atlantic.
\end{abstract}

Communicated by J. D. Reimer

Electronic supplementary material The online version of this article (doi:10.1007/s12526-015-0431-8) contains supplementary material, which is available to authorized users.

Bert W. Hoeksema

bert.hoeksema@naturalis.nl

1 Naturalis Biodiversity Center, PO Box 9517, 2300 RA Leiden, The Netherlands

2 Institute of Biology Leiden, Leiden University, PO Box 9505, 2300 RA Leiden, The Netherlands

3 Global Change Institute, The University of Queensland, St Lucia, QLD 4072, Australia

4 Department of Vertebrate Zoology, National Museum of Natural History, Smithsonian Institution, Washington, DC 20560, USA
Keywords Coral community $\cdot$ Depth records $\cdot$ Foliaceous corals $\cdot$ Manned submersible $\cdot$ Reef fishes $\cdot$ Zooxanthellate corals

\section{Introduction}

Lower mesophotic reef communities ( $>60 \mathrm{~m}$ ) consisting of zooxanthellate scleractinians remain largely unstudied due to the logistical difficulty of accessing depths well below regular diving limits. Traditionally, manned submersibles have been used to explore much greater depths (>200 m), and only sporadically they have been employed to investigate deeper sections of tropical coral reefs that include the depth limits of zooxanthellate corals (e.g., Fricke and Schuhmacher 1983; Reed 1985; Macintyre et al. 1991). Only a few studies with manned submersibles concentrated on azooxanthellate coral assemblages or deep-sea communities containing scleractinians (e.g., Fricke and Hottinger 1983; Tempera et al. 2015; Wisshak et al. 2015). Novel technologies, such as Remotely Operated Vehicles (ROVs) and Autonomous Underwater Vehicles (AUVs) have provided alternative methods of accessing these deep-water communities, but are dependent on camera systems and lack the ability of in situ observations by the human eye (e.g. Webster et al. 2008; Bongaerts et al. 2013b; Englebert et al. 2014; Appeldoorn et al. 2015).

In general, the density and reef-building capacity of zooxanthellate corals decrease with increasing depth, usually resulting in very low coral cover at lower mesophotic depths (Kahng et al. 2010). An exception to this general trend are the Leptoseris-dominated communities that have been observed at 70-90 m depth in Hawaii that can form dense communities of up to $100 \%$ coral cover (Kahng and Maragos 2006; Pochon et al. 2015). Footage and dredge samples taken at the Great Barrier Reef also show that Leptoseris species can 
be locally dominant at greater mesophotic depths but they have not particularly been recorded in high densities yet (Hopley et al. 2007; Bridge et al. 2012; Dinesen et al. 2012). The present report describes the discovery of a large, similarly dense aggregation of Agaricia corals from the same family (Agariciidae) at 70-85 $\mathrm{m}$ depth and some of its demersal fish fauna as observed from the submersible Curasub, based at Substation Curaçao (http://www.substation-curacao.com/).

\section{Material and methods}

On 21 March 2014, the submersible Curasub was transported on board its mother ship, the R/V Chapman, to the reef at Playa Porto (N12 $14^{\prime} 01^{\prime \prime} \mathrm{W} 068^{\circ} 53^{\prime} 32^{\prime}$ ), on the leeward side of Curaçao. The submersible launch platform was anchored in $5 \mathrm{~m}$ deep water, from where two submersible dives were made: one in the morning (1110-1335 hrs) down to $211 \mathrm{~m}$ depth and one in the afternoon (1400-1645 hrs) down to $169 \mathrm{~m}$, with an intermediate change of crew and observers. Depth and temperature were measured by the submersible's gauges, and video was recorded during the $2^{\text {nd }}$ dive (Electronic Supplementary Material=ESM 1).

\section{Results and discussion}

During both dives, the submersible passed over a dense coral community overgrowing a steep rocky slope and a terrace at
$70-85 \mathrm{~m}$ depth. Water temperature varied from 26 to $24{ }^{\circ} \mathrm{C}$ in the morning and from 26 to $22^{\circ} \mathrm{C}$ in the afternoon across that depth gradient. The coral assemblage consisted entirely of thin foliaceous colonies of Agaricia (Agariciidae) of up to nearly $100 \%$ cover (Fig. 1a, b). It is unclear whether the assemblage was mainly composed of A. grahamae Wells, 1973 or A. undata (Ellis and Solander, 1786), because no samples were taken. Both species look alike from a distance and show much overlap in depth range (Humann and Deloach 2013). The presence of Agaricia corals at $>60 \mathrm{~m}$ depth is not uncommon at Curaçao. At the reef off the Curaçao Sea, Aquarium $A$. grahamae and A. undata are dominant coral species at 60$100 \mathrm{~m}$ depth (Bongaerts et al. 2015), but they are not densely aggregated there as they are in the site observed in this study, where the size and cover of the assemblage at 70-85 $\mathrm{m}$ depth is unusual. At Puerto Rico, A. undata has also been observed as the most abundant scleractinian coral at $70 \mathrm{~m}$ depth (with only 10 and $13 \%$ cover) but it is not more dominant than sponges and coralline algae here (Appeldoorn et al. 2015).

Most corals were alive, very few were white and appeared to have bleached or may have died recently (Fig. 1c). Dead corals were generally intact but overgrown by crustose coralline algae. The living coral plates were dark brown at the center, light brown distal to the center, and white at the outer margin (Fig. 1; ESM 1). This colour pattern has also been observed in thin coral plates at the leeward side of Curaçao (Bongaerts et al. 2013a: Fig. 7). The lighter colour is caused by the thin skeletal growth that allows light to penetrate through the calcium carbonate
Fig. 1 Agaricia reef community at 70-85 $\mathrm{m}$ depth, leeward side of Curaçao: a downslope view from $\sim 75 \mathrm{~m}$; b upslope view at $\sim 85 \mathrm{~m}$; c bleached or recently dead corals at $68 \mathrm{~m}$; $\mathbf{d}$ one Paranthias furcifer with a parasitic isopod (arrow)

skeleton, whereas the dark color is caused by algal overgrowth at the underside.

It is also clear that the corals are important as fish habitat. Numerous fishes were swimming over the coral plates, representing at least the following species: Cephalopholis cruentata (Lacepède, 1802) and Paranthias furcifer (Valenciennes, 1828) (Serranidae); Chromis enchrysura Jordan and Gilbert, 1882, and Chromis cyanea (Poey, 1860) (Pomacentridae); Haemulon vittatum (Poey, 1860) and $H$. flavolineatum (Desmarest, 1823) (Haemulidae); Neoniphon marianus (Cuvier, 1829) (Holocentridae); Clepticus parrae (Bloch and Schneider 1801) (Labridae); and Scarus taeniopterus Lesson, 1829 (Scaridae) (ESM 1). These fishes mainly hovered or swam above coral, but a few were observed to seek shelter within the coral aggregation (ESM 1: $33 \mathrm{sec}$ ). At least three individuals of $P$. furcifer hosted large parasitic cymothoid isopods (Fig. 1d, ESM 1: $1 \mathrm{~min} 35 \mathrm{sec}$ ). No attempt was made to investigate the presence or absence of smaller fishes living cryptically in the coral.

None of the observed fish species is uncommon, and most have been reported at similar depths off the Bahamas, Belize, Florida, Jamaica, or Puerto Rico (Colin 1974, 1976; Itzkowitz et al. 1991; Bryan et al. 2013; Bejarano et al. 2014). Haemulon flavolineatum was previously recorded only down to $50 \mathrm{~m}$ (Itzkowitz et al. 1991; Robertson and Van Tassell 2015). There is a general paucity of information regarding Caribbean deep-reef fish communities. Our knowledge of their depth distributions and community structure increases measurably through video-documented studies such as the one presented here.

Deep reef communities can be studied very well from manned submersibles that are equipped with sample tools and cameras, which enables the researchers to remain relatively comfortable underwater for some hours and to observe and collect anything attracting attention. This has resulted in mesophotic depth records of three reef fish species during the present dives, and a fourth one during another dive session (Baldwin and Robertson 2015). New information obtained in such a way can be important for clarifying the possible role of deep reef assemblages in coral reef conservation with regard to global change (Bongaerts et al. 2010). The Curasub has also been indispensable in the recent discovery of new fish species at Curaçao, from mesophotic depths at 70-80 m (Baldwin and Robertson 2015 ) to depths at 120-300 m (e.g., Baldwin and Robertson 2013, 2014; Baldwin and Johnson 2014), as well as new species of deep-living molluscs from 130-315 m depth (Harasewych 2014; Harasewych and Tëmkin 2015), and sponges from 145-160 m depth (van Soest et al. 2014). Recent dives off Substation Curaçao resulted in a second locality record for an echinoid-associated deep-water shrimp (Fransen 2014) and a depth record for an Agariciaassociated gall crab (Van der Meij et al. 2015).
Discarded fish lines were seen over the assemblage (ESM 1). Used beer bottles and cans were observed on both dives, although this is not visible in the video. Such items, car tires, and anchors were also seen at great depths near Sea Aquarium (Bongaerts et al. 2015). This implies that even deep reefs are not immune to anthropogenic impact, and should therefore be included in the planning of marine protected areas.

Acknowledgements The authors want to thank Adriaan "Dutch" Schrier, Laureen Schenk, and the crews of the Curasub and R/V Chapman based at Substation Curaçao, for their hospitality and help. The first author is grateful to CARMABI for providing research facilities. The video is courtesy of Substation Curaçao. Ross Robertson, Smithsonian Tropical Research Institute, helped with the fish identifications. Cristina Castillo, Project Coordinator for the Smithsonian's Deep Reef Observation Project (DROP), provided logistical and technical support. Two anonymous reviewers provided constructive remarks. This publication is Ocean Heritage Foundation / Curaçao Sea Aquarium / Substation Curaçao (OHF/CSA/SC) contribution number 20.

Open Access This article is distributed under the terms of the Creative Commons Attribution 4.0 International License (http:// creativecommons.org/licenses/by/4.0/), which permits unrestricted use, distribution, and reproduction in any medium, provided you give appropriate credit to the original author(s) and the source, provide a link to the Creative Commons license, and indicate if changes were made.

\section{References}

Appeldoorn R, Ballantine D, Bejarano I, Carlo M, Nemeth M, Otero E, Pagan F, Ruiz H, Schizas N, Sherman C, Weil E. (2015) Mesophotic coral ecosystems under anthropogenic stress: a case study at Ponce, Puerto Rico. Coral Reefs. doi:10.1007/s00338-015-1360-5

Baldwin CC, Johnson GD (2014) Connectivity across the Caribbean Sea: DNA barcoding and morphology unite an enigmatic fish larva from the Florida Straits with a new species of sea bass from deep reefs off Curaçao. PLoS ONE 9(5):e97661. doi:10.1371/journal.pone. 0097661

Baldwin CC, Robertson RD (2013) A new Haptoclinus blenny (Teleostei, Labrisomidae) from deep reefs off Curaçao, southern Caribbean, with comments on relationships of the genus. ZooKeys 306:71-81. doi:10.3897/zookeys.306.5198

Baldwin CC, Robertson RD (2014) A new Liopropoma sea bass (Serranidae, Epinephelinae, Liopropomini) from deep reefs off Curaçao, southern Caribbean, with comments on depth distributions of western Atlantic liopropomins. ZooKeys 409:71-92. doi:10. 3897/zookeys.409.7249

Baldwin CC, Robertson DR (2015) A new, mesophotic Coryphopterus goby (Teleostei, Gobiidae) from the southern Caribbean, with comments on relationships and depth distributions within the genus. ZooKeys 513:123-142. doi:10.3897/zookeys.513.9998

Bejarano I, Appeldoorn RS, Nemeth M (2014) Fishes associated with mesophotic coral ecosystems in La Parguera, Puerto Rico. Coral Reefs 33:313-328. doi:10.1007/s00338-014-1125-6

Bongaerts P, Ridgway T, Sampayo EM, Hoegh-Guldberg O (2010) Assessing the 'deep reef refugia' hypothesis: focus on Caribbean reefs. Coral Reefs 29:309-327. doi:10.1007/s00338-009-0581-x 
Bongaerts P, Frade PR, Ogier JJ, Hay KB, van Bleijswijk J, Englebert N, Vermeij MJA, Bak RPM, Visser PM, Hoegh-Guldberg O (2013a) Sharing the slope: depth partitioning of agariciid corals and associated Symbiodinium across shallow and mesophotic habitats (2-60 m) on a Caribbean reef. BMC Evolutionary Biology 13:205. doi:10. 1186/1471-2148-13-205

Bongaerts P, Muir P, Englebert N, Bridge TCL, Hoegh-Guldberg O (2013b) Cyclone damage at mesophotic depths on Myrmidon Reef (GBR). Coral Reefs 32:935-935. doi:10.1007/s00338-013-1052-y

Bongaerts P, Frade PR, Hay KB, Englebert N, Latijnhouwers KRW, Bak RPM, Vermeij MJA, Hoegh-Guldberg O (2015) Deep down on a Caribbean reef: lower mesophotic depths harbor a specialized coralendosymbiont community. Sci Rep 5:7702. doi:10.1038/srep07702

Bridge TCL, Fabricius KE, Bongaerts P, Wallace CC, Muir PR, Done TJ, Webster JM (2012) Diversity of Scleractinia and Octocorallia in the mesophotic zone of the Great Barrier Reef, Australia. Coral Reefs 31:179-189. doi:10.1007/s00338-011-0828-1

Bryan DR, Kilfoyle K, Gilmore RG, Spieler RE (2013) Characterization of the mesophotic reef fish community in south Florida, USA. J Appl Ichthyol 29:108-117. doi:10.1111/j.1439-0426.2012.02055.x

Colin PL (1974) Observations and collection of deep-reef fishes off the coasts of Jamaica and British Honduras (Belize). Mar Biol 24:29 38. doi:10.1007/BF00402844

Colin PL (1976) Observations of deep reef fishes in the tongue-of-theocean, Bahamas. Bull Mar Sci 26:603-605

Dinesen ZD, Bridge TCL, Luck DG, Kahng SE, Bongaerts P (2012) Importance of the coral genus Leptoseris to mesophotic coral communities in the Indo-Pacific. Poster 12th International Coral Reef Symposium, Cairns, 2012: P101. http://www.icrs2012.com/ eposters/P101.pdf

Englebert N, Bongaerts P, Muir P, Hay KB, Hoegh-Guldberg O (2014) Deepest zooxanthellate corals of the Great Barrier Reef and Coral Sea. Mar Biodiv 45:1-2. doi:10.1007/s12526-014-0221-8

Fransen CHJM (2014). A second discovery of Diapontonia maranulus Bruce, 1986 (Crustacea: Decapoda: Palaemonidae) in the Caribbean. Zootaxa 3881:591-596. doi:10.11646/zootaxa.3881.6.8

Fricke H, Hottinger L (1983) Coral bioherms below the euphotic zone in the Red Sea. Mar Ecol Prog Ser 11:113-117

Fricke HW, Schuhmacher H (1983) The depth limits of Red Sea stony corals: An ecophysiological problem (a deep diving survey by submersible). Mar Ecol 4:163-194

Harasewych MG (2014) Attenuiconus marileeae, a new species of cone (Gastropoda: Conidae: Puncticulinae) from Curaçao. The Nautilus 128:55-58

Harasewych MG, Tëmkin I (2015) The Miocene genus Mantellina (Bivalvia: Limidae) discovered living in the deep reefs off Curaçao, with the description of a new species. J Moll Stud 81: 442-454. doi:10.1093/mollus/eyv021
Hopley D, Smithers SG, Parnell KE (2007) The geomorphology of the Great Barrier Reef: development, diversity and change. Cambridge University Press, Cambridge, United Kingdom

Humann P, Deloach N (2013) Reef Coral Identification: Florida, Caribbean \& Bahamas (3rd Edition) New World Publications. Jacksonville, FL

Itzkowitz M, Haley M, Otis C, Evers D (1991) A reconnaissance of the deeper Jamaican coral reef fish communities. Northeast Gulf Sci 12: 25-34

Kahng SE, Maragos JE (2006) The deepest zooxanthellate, scleractinian corals in the world? Coral Reefs 25:254. doi:10.1007/s00338-0060098-5

Kahng SE, Garcia R, Spalding HL, Brokovich E, Wagner D, Weil E, Hinderstein L, Toonen RJ (2010) Community ecology of mesophotic coral reef ecosystems. Coral Reefs 29:255-275. doi: 10.1007/s00338-010-0593-6

Macintyre IG, Rützler K, Norris JN, Smith KP, Cairns SD, Bucher KE, Steneck RS (1991) An early Holocene reef in the western Atlantic: submersible investigations of a deep relict reef off the west coast of Barbados, WI. Coral Reefs 10:167-174. doi:10.1007/BF00572177

Pochon X, Forsman ZH, Spalding HL, Padilla-Gamiño JL, Smith CM, Gates RD (2015) Depth specialization in mesophotic corals (Leptoseris spp.) and associated algal symbionts in Hawai'i. Roy Soc Open Sci 2(2):140351. doi:10.1098/rsos.140351

Reed JK (1985) Deepest distribution of Atlantic hermatypic corals discovered in the Bahamas. Proc 5th Int Coral Reef Symp 6:249-254

Robertson DR, Van Tassell J (2015) Shorefishes of the Greater Caribbean: online information system. Version 1.0 Smithsonian Tropical Research Institute, Balboa, Panamá

Tempera F, Carreiro-Silva M, Jakobsen K, Porteiro FM, Braga-Henriques A, Jakobsen J (2015) An Eguchipsammia (Dendrophylliidae) topping on the cone. Mar Biodiv 45:3-4. doi:10.1007/s12526-0140220-9

van der Meij SET, van Tienderen KM, Hoeksema BW (2015) A mesophotic record of the gall crab Opecarcinus hypostegus from a Curaçaoan reef. Bull Mar Sci 91:205-206. doi:10.5343/bms.2014. 1072

van Soest RWM, Meesters EH, Becking LE (2014). Deep-water sponges (Porifera) from Bonaire and Klein Curaçao, Southern Caribbean. Zootaxa 3878:401-443. doi: 10.11646/zootaxa.3878.5.1

Webster JM, Beaman RJ, Bridge T, Davies PJ, Byrne M, Williams S, Manning P, Pizarro O, Thornborough K, Woolsey E, Thomas A, Tudhope S (2008) From corals to canyons: the Great Barrier Reef margin. EOS Trans Am Geophys Union 89:217-218. doi:10.1029/ 2008EO240002

Wisshak M, Berning B, Jakobsen J, Freiwald A (2015) Temperate carbonate production: biodiversity of calcareous epiliths from intertidal to bathyal depths (Azores). Mar Biodiv 45:87-112. doi:10.1007/ s12526-014-0231-6 